\title{
Teacher language awareness and world Englishes - where (corpus) linguistics, digital literacy and teacher training meet
}

\begin{abstract}
In the rapidly changing world of today, the role of English as a global language is not to be left unnoticed in pre-service teacher training. Teacher language awareness, encompassing knowledge of language, knowledge about language and knowledge of students, needs to be expanded with the wider sociocultural context in which language education takes place in different parts of the world. At the same time, the changes in the very shape of English and the emergence of World Englishes, New Englishes, English as an International Language and English as a Lingua Franca call for skilful implementation of these concepts in the practice-oriented teacher training module. The paper reports upon a study aiming at joining corpus-based investigations, student-made research into sociocultural context of English learning and use, coursebook analysis and lesson plan evaluation and adaptation into a single Teaching English as an International Language course included in a graduate TEFL module. Results of the study indicate that the experimental treatment brought about statistically significant, though small in effect size, changes in language awareness of prospective teachers in a great number of aspects.
\end{abstract}

Keywords: World Englishes, Data-Driven Learning, corpus linguistics, teacher language awareness.

\section{Introduction}

While most university programmes dealing with language teacher training contain courses devoted to linguistics on the one hand and digital literacy on the other, it is rarely the case that they are actually integrated with the content of professional training to a sufficient extent. At the same time, the globalized world of contemporary language classroom or translation market necessitates enlarged language competence, increased awareness of standard and non-standard English, at least general knowledge of New Englishes and nativization processes happening in different parts of the world, which must involve sound linguistic background on the one hand and specific technical competences on the other.

1 Address for correspondence: Institute of German Studies and Applied Linguistics, Maria Curie-Skłodowska University, Plac M. C. Sklodowskiej 4a, 20-031 Lublin, Poland. E-mail: jarek.krajka@poczta.umcs. lublin.pl 
Our purpose in the present paper is to argue that corpus linguistics, digital literacy and teacher training are the three areas that should be intertwined to help increase prospective teachers' awareness of English(es). The discussion will be substantiated by the findings from a corpusassisted Teaching English as an International Language component in a graduate teacher training programme, showing how to integrate the three areas into a successful instructional module.

\section{Teacher language awareness - towards the diversity of English(es)}

The issue of teachers' language awareness of diversity of Englishes has entertained quite a lot of research (e.g., Carter 1995; Crystal 2010; Farrell \& Martin 2009; Hazen 2001; Dziubalska-Kołaczyk 2005; Rinvolucri 2006). Harmer (2007) mentions some factors which need to be considered while choosing the model of English to be taught in the classroom:

- the wishes and needs of learners,

- the variety teachers themselves use,

- the availability of teaching/learning materials,

- education authority policy.

When reflecting on what kind of language input to provide in the classroom and how to use it for assessment purposes, Crystal (1999) points out that teachers may have to distinguish between production and reception skills - in terms of the former, 'pedagogical conservatism' is advised, which is about deciding to teach a particular variety and sticking to it. As for reception, Crystal (1999) insists on 'pedagogical innovation,' exposing learners to as many varieties of English as possible, which these days should not be too challenging (Matsuda 2003). When teaching English to non-native speakers who will use it in the English as an International Language context, Maley (2010) has a similar view, suggesting that the teacher should expose students to different Englishes in the comprehension mode, highlight that it is only one of many varieties of English but be very clear about teaching grammar and demand the production of only its standard variety.

The fact that it is only British or American English that is used for grammar instruction and assessment benchmark for oral or written production does not mean that other Englishes should not be brought to light. Failure to bring this linguistic diversity into the language classroom can result in, as is claimed by Matsuda (2002), confusion, resistance or even astonishment of students when they are confronted with different types of English and its uses that divert from the Standard English (Inner Circle) model.

At the same time, we need to remember that teacher language awareness is not only about knowledge of which English to teach and assess against. As defined by Hall (2011), teacher language awareness is the combination of three areas of knowledge: knowledge of the language (actual language facility); knowledge about the language (meta-linguistic knowledge and the ability to verbalise it) and knowledge of the students (the ability to see the effect of student characteristics on language instruction). Thus, all the three components need to be brought together in an effective language teacher training programme. Ideally, within a single subject, such as Teaching English 
as an International Language as described below, the three perspectives need to be juxtaposed but also put aside to see how they are complementary rather than contradictory.

\section{General picture of new Englishes (Crystal 2005)}

It is an imperative for language teachers to be up-to-date with the current changes in the language they are going to teach. Failure to become aware of how English is changing and in which directions the changes might be proceeding means that teachers are likely to teach obsolete language - either the one that they acquired themselves as learners a number of years before or the one that is "pre-packaged" for them in globally-published ELT coursebooks.

Interesting changes in the role and status of English that we are experiencing nowadays should not be unnoticed in teacher training programmes. As David Crystal (2005) remarks, communities which are putting English to use are doing so in several different ways, which results in the emergence of Englishes (pluralized), not only World Englishes based on geographical or socio-historical criteria (countries belonging to the Commonwealth, for instance), but also New Englishes appearing in all those contexts in which English starts to play a paramount role in the society.

According to Crystal (2005), a New English is not a homogeneous entity, with clear-cut boundaries, and an easily definable phonology, grammar and lexicon. Instead, it is a hybrid mixing English and native language(s), in different ways and to a different extent, ranging from single lexical borrowings, adapted or not, to several borrowings even resulting in a sentence being indistinguishable from standard English. A sentence might use so many words and constructions from a contact language that it becomes unintelligible to those outside a particular community. Those varying degrees of hybridization can be even visible in consecutive sentences of particular speakers in the same conversation, where, most probably, the familiarity with the topic and easiness of expressing oneself results in more or less unconscious language choices. An interesting example of this mixed-degree hybridization is visible in Figure 1 below.

\footnotetext{
CHANDRA: Lee Lian, you were saying you wanted to go shopping, nak pergi tak?

LEE LIAN: Okay, okay, at about twelve, can or not? CHANDRA: Can lah, no problem one! My case going to be adjourned anyway.

LEE LIAN: What you looking for? Furnitures or kitchenwares?

You were saying, that day, you wanted to beli some barang barang for your new house.

CHANDRA: Yes lah! Might as well go window-shopping a bit at least. No chance to ronda otherwise. My husband, he got no patience onc!

LEE LIAN: You mean you actually think husbands got all that patience ah? No chance man! Yes or not?

CHANDRA: Betul juga. No chance at all! But if anything to do with their stuff - golf or snooker or whatever, then dia pun boleh sabar one.
}

Figure 1. English-Malay code mixing (Crystal 2005: 166) 
In terms of vocabulary, borrowings from indigenous languages are especially noticeable, which is because the amount of borrowing from a local language is extremely sensitive to sociopolitical pressures. It is influenced by both the number of cultures which co-exist and the status which their languages have achieved (Crystal 2005). A word or a phrase from a well-established variety may be adopted by a New English and given a new meaning or use without undergoing any structural change, or, on the contrary, there may be adaptation processes at work, either the ones belonging to the structural pattern of English (e.g., compounding - car lifter, luggage lifter, book lifter, distinctive prefixation/suffixation - endeavourance, ruinification, cronydom, abscondee, wheatish, scapegoatism, word-class conversion - to aircraft, to slogan, to tantamount, the injureds, the deads or abbreviation, clipping and blending - $d / o$ ('daughter of '), $r / o$ ('resident of'), admit card, by-polls) or the word formation rules of indigenous language(s).

In terms of semantics, as David Crystal (2005) reports, there are many instances in which a word or phrase from a well-established variety is adopted by a New English and given a new meaning or use, without undergoing any structural change (heavy in the sense of 'gorgeous', brutal in the sense of 'very nice'), thus, semantic shifts can be noticed (maiden name meaning 'given name' applied to males or linguist meaning 'spokesman for the chief'). Finally, there are also many words which keep the same meaning, but display a different frequency of use compared with British or American English, such as the greater frequency of Jamaican bawl ('shout', 'weep').

While vocabulary changes are, obviously, of interest to language teachers, they are not likely to result in much instruction going on, apart from, perhaps, the use of idiosyncratic examples for explaining word formation processes. At the same time, idiosyncratic grammatical structures appearing in New Englishes video subtitles, song lyrics, newspaper articles or ad slogans require much greater attention, since the linguistic character of grammar of New Englishes is more complex. On the one hand, there is little differentiation as for grammar and there is an impression of relative sameness. Grammar changes are much slower to enter the language than it is the case with vocabulary, mainly because grammars are based on written language which is generally more formal, takes educated usage as its corpus basis and is much more reluctant to welcome innovations. On the other hand, as the list of examples from Baumgardner (1990), Kachru (1994), Baskaran (1994) or Mesthrie (1992, 1993a, 1993b) brought below shows, variations are noted with respect to aspect, modals, negation, concord, pronouns, complementation and several other areas. While in some cases (e.g., reduplication or word order in questions) they might be accepted by learners as indicators of colloquial language without much influence on the rules grounded in their competence, many others require confrontation with standard usage and explicit explanation pointing out its idiosyncratic nature and possible sociocultural consequences of usage by learners in L2-speaking communities.

- Myself I do not know him

- That man he is tall

- They two very good friends

- I am understanding it now 
- I have been singing yesterday

- She is crying why?

- You stay here first, can or not?

- You are coming to the meeting, isn't it?

- We waited-waited for him

- equipments, luggages, furnitures, damages, aircrafts

- a good advice/a luggage

- more better/junior than

- quick-quick, now-now, who-who, big big fish

What becomes evident, then, is that there arises a need to find proper procedures for student teachers to gain awareness of how to confront such non-standard usage with more established examples, what particular standard of English is actually sought in the institution where they are most likely to work, what are the attitudes towards varieties of English in the target teaching context. While encountering such non-standard examples, student teachers need to know how to cope with them both during lesson preparation (e.g., to check their frequency, to isolate the very English it comes from) and implementation (if, for instance, such examples appear in a less predictable way).

\section{Reconciling corpus linguistics, digital literacy and teaching skills - a training proposal}

\subsection{Implementing corpus-based procedures in a TEIL class}

Corpus linguistics and its corresponding language teaching area, Data-Driven Learning, have been flourishing for years, and it is no wonder that they can effectively enhance the impact of teacher training within a Teaching as an International Language context. To quote just a few studies, we have witnessed the use of small corpora to respond to students' needs (Aston 1997) vs. large corpus concordancing (Bernardini 2000; de Schryver 2002); concordancing used to improve writing performance at lower (Yoon \& Hirvela 2004; Gaskell \& Cobb 2004) and advanced levels (Chambers \& O’Sullivan 2004); grammar presentation (Hadley 2002) and rule inferencing (St. John 2001); vocabulary acquisition (Cobb 1997; Cobb 1998) and foreign language reading (Cobb et al. 2001; Horst et al. 2005). An interesting perspective, the one which is also seen on the horizon of the present study, is learner corpus self-compilation (Lee \& Swales 2006). Even though there have been studies into the use of corpora in teacher training (e.g., Lewandowska-Tomaszczyk 2001; LeńkoSzymańska 2005; Kaszubski 2006), there have been few attempts to actually combine Data-Driven Learning procedures with context-based language instruction and buildup of global teaching skills.

Since, as we claim elsewhere (Krajka 2015), building language teachers' awareness and making them ready to deliver language instruction in multiple cultural contexts needs to go beyond the usual set of methodology-related concepts, ample reflection is needed on how sociolinguistics, corpus linguistics, language policy and planning and educational practice are to be effectively brought together in a teacher training programme. Most importantly, as we try to demonstrate 
in the present study, it is not enough to cover the usual set of concepts, theories and approaches in terms of English as a Foreign/Second Language. More importantly, teacher trainees need to see in practice the two sides of the language teaching reality in different parts of the world - on the one hand, the linguistic aspect, namely, the knowledge of the inter- and intralingual influence of English on the native language and vice versa, and, on the other hand, the effect of local conditions/organizational cultures/learning habits on the way a foreign language is taught and assessed.

Teacher trainees might be involved in cross-linguistic analyses comparing, for instance, British and American English as Inner Circle countries, Jamaican or Singaporean English as Outer Circle countries or Spanish English (Spanglish) or Saudi English as Expanding Circle countries. Once such teacher-led investigations are done, for instance, with online corpora collected at Corpus. byu.edu (see Figure 2 below), teacher trainees can effectively gain searching skills based on the same query interface, yet changing corpora or subcorpora to gain different points of reference. This means not being confined to one particular corpus, but rather doing a kind of "semi-guided treasure hunt" task, in which teacher trainees are given tasks and are instructed in how to use a particular query interface (here, corpus.byu.edu), however, they are not told exactly which corpus to go to in order to find the very answers.

\begin{tabular}{|c|c|c|c|c|}
\hline English & \# words & language/dialect & time period & compare \\
\hline News on the Web (NOW) & 5.41 billion+ & 20 countries / Web & 2010-yesterday & \\
\hline Global Web-Based English (GloWbE) & 1.9 billion & 20 countries / Web & $2012-13$ & \\
\hline Wikipedia Corpus & 1.9 billion & English & -2014 & Info \\
\hline Hansard Corpus & 1.6 billion & British (parliament) & $1803-2005$ & Info \\
\hline Early English Books Online & 755 million & British & $1470 s-1690 s$ & \\
\hline Corpus of Contemporary American English (COCA) & 520 million & American & $1990-2015$ & $* * * * *$ \\
\hline Corpus of Historical American English ( $\mathrm{COHA})$ & 400 million & American & $1810-2009$ & ** \\
\hline Corpus of US Supreme Court Opinions & 130 million & American (law) & 1790s-present & \\
\hline TIME Magazine Corpus & 100 million & American & $1923-2006$ & \\
\hline Corpus of American Soap Operas & 100 million & American & $2001-2012$ & * \\
\hline British National Corpus (BYU-BNC)* & 100 million & British & $19805-1993$ & * * \\
\hline Strathy Corpus (Canada) & 50 million & Canadian & $1970 s-2000 s$ & \\
\hline CORE Corpus & 50 million & Web registers & -2014 & \\
\hline \multicolumn{5}{|l|}{ Other languages } \\
\hline Corpus del Español (see also...) & 2.1 billion & Spanish & $1200 s-1900 s$ & * \\
\hline Corpus do Português (see also...) & 1.1 billion & Portuguese & $1300 \mathrm{~s}-1900 \mathrm{~s}$ & \\
\hline \multicolumn{5}{|l|}{ N-grams } \\
\hline Google Books: American English & 155 billion & American & $1500 s-2000 s$ & * \\
\hline Google Books: British English & 34 billion & British & $1500 s-2000 s$ & \\
\hline Google Books: Spanish & 15 billion & Spanish & $1500 s-2000 s$ & \\
\hline
\end{tabular}

Figure 2. Freely available corpora demonstrating diverse Englishes collected at Corpus.byu.edu 
Quite understandably, as regards Expanding Circle countries, they are not likely to be represented in the freely available corpora. For that matter, the instructor would have to compile a teacher-made mini-corpus, for instance, out of newspaper articles, literature repositories, legislation databases, specialist discussion group postings and digests, equipment manuals, encyclopedia articles, which would adhere to a clear set of criteria in terms of a regional and diachronic variety of English, text type (spoken/written, news, fiction, legal texts etc.), text register, text purpose (general reference or specific purpose) or source authority.

Learner training in corpus use (either ready-made, such as Corpus.byu.edu, or teacher-made), might go along one of the following procedures:

- the "apprenticeship model" of classroom concordancing, which aims at promoting learning by example and experience, where corpus-based activities are carried out gradually, with $\mathrm{T}$ giving directions and asking additional questions, while Ss working in small groups and later reporting to the whole class (Jones 1991);

- the three-step model comprising identifying which words to investigate (in this case items on the high-frequency PET word list); giving learners access to take away lexical information in hard copy (or else most of the lab hour was spent transcribing from the screen); building in motivation for considering each word in several sentence contexts (Cobb 1999);

- the question-search-conclusion strategy: formulating the question: e.g., 'Which preposition can be used after orario when speaking of a timetable for something?'; devising a search strategy; observing the examples and select relevant ones; drawing conclusions (Kennedy \& Miceli 2001).

Other language-related tasks successfully used in English for Academic Purposes studies (e.g., Gaskell \& Cobb 2004; Marinov 2013) might be as follows:

- Lexical cloze - completing gaps in sentences with selected options (e.g., multiple adjectives to be chosen from);

- Colligation - matching verbs and prepositions to find patterns;

- Learning more about the word - following guiding questions to find out more about selected words (e.g., how frequent it is, is it more frequent in oral or written language, is it formal or colloquial, what are its most frequent left/right collocates);

- Analyse the differences - scrutinizing selected concordances to make conclusions about what makes similar words different - e.g., alone and lonely or packed and crowded;

- Word-class gap-fill - completing texts with provided words, either giving them the nominal or verbal shape depending on the context, finding help through left/right context search in a corpus;

- Corpus-based error correction - providing erroneous sentences (e.g., the ones containing frequent mistakes made by Polish learners of English) and a set of concordance lines (or instructions for corpus queries for students to find data themselves) to trigger correction. 


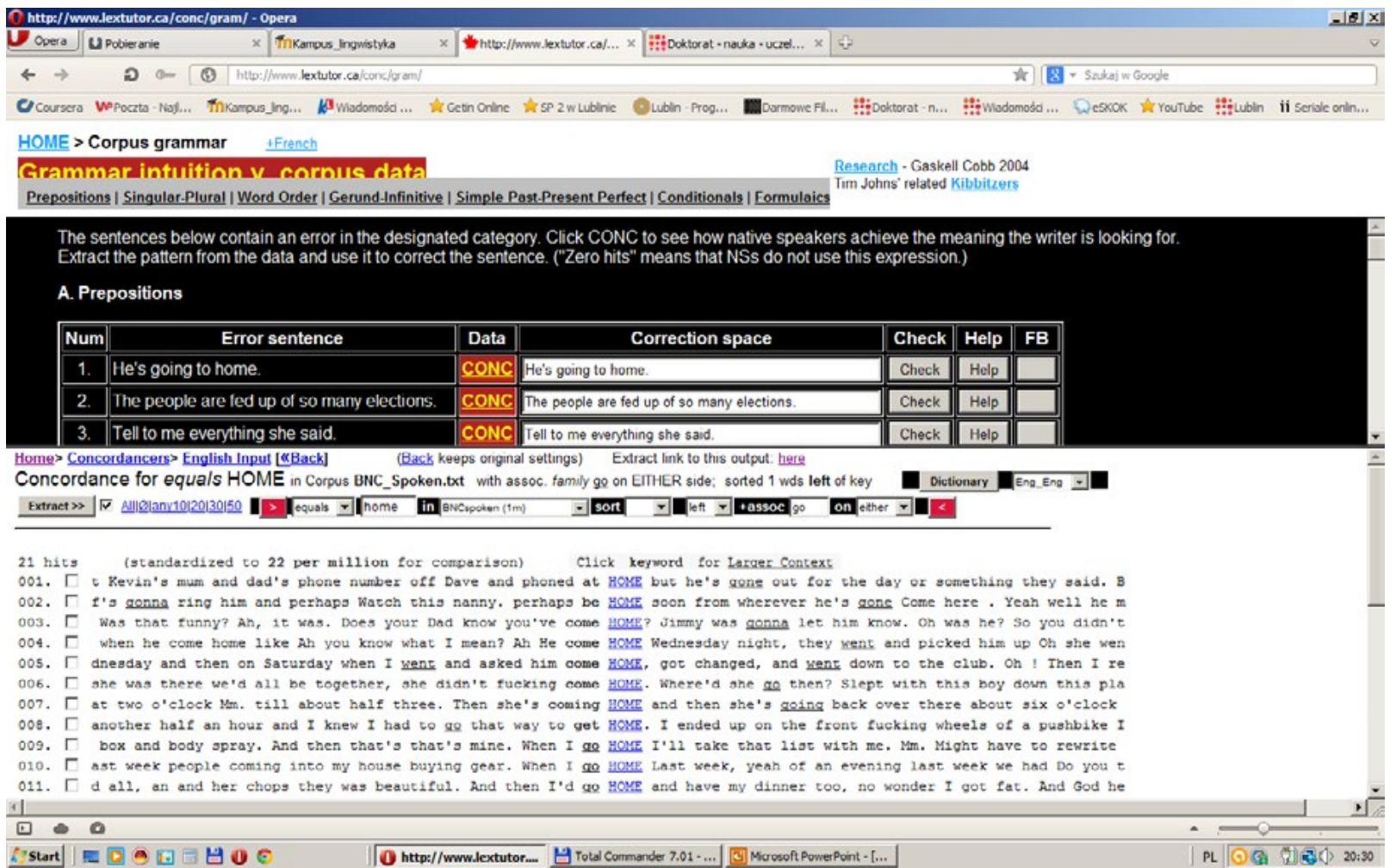

Figure 3. A sample corpus-based error correction task available at Lextutor (Gaskell \& Cobb 2004)

Depending on how advanced teacher trainees are or how quickly they grasp concordancing procedures, possible avenues to extend the study of World Englishes via corpus-based tasks might encompass the following activities:

1. Students compile their own mini-corpora for use with IntelliText/TextSTAT from a clearly narrowed down domain (e.g., Wikipedia articles about Russian pop stars in English; Russian-based discussion forums in English).

2. Students extract samples of language (e.g., from tabloid English-language newspapers from two different Expanding Circle countries) and compare them to isolate key differences in usage or frequency using Lextutor's Text-Lex Compare or IntelliText.

3. Students create tasks based on language problems that are isolated by the instructor from relevant literature (e.g., characteristic features of Russian English).

4. Students take one another's tasks and try to solve them assisted by GloWBE corpus or a teacher-made corpus.

5. Students take the tasks from step 4 and try to solve them using a different corpus than before, afterwards, they are guided to make generalizations.

6. Students reach conclusions on how effective Data-Driven Learning is for studying World Englishes and for confronting their own writing pieces with either Inner Circle or Expanding Circle corpora. 


\subsection{Framing language methodology in the sociocultural context}

Studying the linguistic characteristics of the English used in different countries of the world, be it Inner Circle countries other than the UK, Outer Circle or Expanding Circle countries, is only one side of expanding the context of English language instruction for teacher trainees. The other important sphere is the awareness of the sociocultural context in which English language education is taking place in a particular part of the world. This encompasses, among others, the status of English in the country, the social distance between the British or American culture and the native culture (Schumann 1976; Brown 1994), the attitudes towards L2 country and its inhabitants, the mutual interrelationships between English and native languages, local preferences for learning and teaching styles and strategies, the way English language instruction is organized at schools etc. While, obviously, it is impossible for teacher trainees to gain knowledge about every single country in the world, it is important for them to see how selected countries compare in terms of role and status of the English language and the organization of English language teaching. Doing individual research, finding and evaluating data sources, investigating legislation and school practice, examining discussion forums or social media grouping English language teachers from a particular country, seeking access to scientific articles on the topic, all enable teacher trainees to become independent researchers gaining awareness of the role societal and political factors play in the way a particular foreign language is taught and learnt, what status the language teacher can have, what aims can be realistically set for students to achieve.

These objectives can be achieved in a Teaching English as an International Language class in multiple ways. Most importantly, teacher trainees are to conduct research on selected countries, prepare and deliver an in-class presentation followed by discussion on the contexts of English language learning and teaching.

TASK 1. FINDING OUT THE CONTEXT FOR LANGUAGE USE AND LANGUAGE LEARNING - COMPARATIVE RESEARCH OF SELECTED COUNTRIES

- Ss select two countries for individual research;

- they investigate status of English, shape of English language teaching, relations between English and native languages, attitudes towards English in the country;

- they gather data from various sources (country articles from World Englishes journal, reports from ministries/statistical offices/school examination boards, videos from YouTube);

- they substantiate their discussion with examples of English-local language relationship (nativisation of English or transfer from English).

For language teachers, it is imperative to understand how coursebooks are responsive to the local needs for which they are targeted, or, on the contrary, how they achieve global reference and impact with no acknowledgement of local cultures of learning. At the same time, teacher trainees need to learn how to notice the "hidden curriculum" in the coursebook, the underlying teaching 
and learning philosophy, the methodology that coursebook authors adhere to. Therefore, coursebook analysis for aspects of culture and language is another important task increasing teacher awareness and expanding upon their global teaching skills.

TASK 2. BUILDING TLA OF WEs - ANALYSING CBs FOR LANGUAGE AND CULTURE

- Ss select three coursebooks for the same target audience - ideally, from different publishers, if possible, both local and global ones;

- they establish their own criteria for analysis of English(es) and cultures;

- they focus on the coverage of different geographical areas and social strata and isolate ingredients of the target culture;

- they analyse the function of various culture-loaded elements (texts, headings, pictures, recordings, titles);

- they make generalisations on the image of language and culture promoted by the coursebooks, reaching conclusions on the most globalised ones;

- they put the results into an essay form, with examples/screenshots/citations, which are later distributed to other teacher trainees via class Moodle for reflection and analysis.

The final important element of situated language instruction as advocated in the present study is work with lesson plans. Teacher-made lesson plans are a useful way for observing how methodology assumptions are operationalised into observable and comparable units. The way teachers educated in different countries use lesson openings and closings, the proportion of various forms of work (pair/groupwork vs. teacher-fronted lockstep vs. individual work), the ways grammatical structures and lexical expressions are introduced and practiced (deductively vs. inductively) or the way learners are assessed on a daily basis are best demonstrated in lesson plans. An important part of TEIL instruction aimed at preparing language teachers of tomorrow to meet challenges of teaching English in multicultural settings is analyzing, evaluating and adapting lesson plans. In the case of the study to follow, these were retrieved from an international MOOC in which the researcher took part himself. Alternatively, rather than use ready-made lesson plans, teacher trainees can be asked to make their own ones that would meaningfully exploit World Englishes to either expand target learners' comprehension skills (oral or written) or make them aware of standard/non-standard features of the phonological, grammatical or lexical system of English. 
TASK 3. BUILDING TLA OF WEs - EVALUATING/ADAPTING LESSON PLANS OR DESIGNING LESSON PLANS BASED ON NEW ENGLISHES

- Ss design two different lesson plans (one focusing on listening comprehension and the other on reading skills) based on a selected New English/World English;

- they use WE materials in the receptive mode, not for language production;

- they learn how to assess the comprehensibility of the text and how to select task/s to achieve appropriate level of difficulty;

- they are careful to design tasks in such a way so as not to locate task answers in too idiosyncratic phrases/constructions.

\section{The study}

\subsection{The aims and context of the study}

A small-scale study was implemented in order to verify the feasibility of the abovementioned teacher training proposal aiming at expanding future teachers' language awareness and encompassing the sociocultural and sociolinguistic dimensions in foreign language teaching. The main objective of the study was to see whether the application of the experimental programme joining corpus linguistics and World Englishes/English as a Lingua Franca with student independent sociolinguistic and sociocultural research and practical tasks of coursebook analysis and lesson plan design would lead to enhanced perception of different components of global teaching skills. A supplementary objective was to verify how feasible such an experimental Teaching English as an International Language course is, what problems or obstacles can be encountered during its implementation and what solutions can be proposed to solve or prevent them.

The context for the study was a middle-sized private university in Warsaw, training future teachers of English in the extramural M.A. programme in English language and literature. The participants of the study were 20 students attending the teaching specialization. All of them completed first-cycle programme in English language teaching and were seeking M.A. to obtain full teaching qualifications. The group comprised 17 females and 3 males, half being 20-25 years of age, onefourth over 35, with the remaining one-fourth spread evenly in the 26-30 and 31-35 age range.

The teaching module at the university, among others, encompassed Teaching English as an International Language course spanning 20 hours in the winter semester of 2016/2017 academic year. The whole teaching module is visible in Figure 4 below. 


\section{Winter term}

"Psychology: Selected Issues"

"Pedagogical Theory: Selected Issues"

"Teaching Children and Adolescents"

"Teaching Adult Learners"

\section{Summer term}

"Lesson Observation and Evaluation"

"Language Testing"

"ELT Materials Evaluation"
"New Trends in Language Education"

"Teaching English as an International Language"

"Teaching English for Specific Purposes"
"Success and Failure in Language Teaching"

"Autonomy in Language Learning and

Teaching"

"Information and Communication

Technology"

Figure 4. Full listing of TEFL module components in the M.A. extramural programme

The syllabus of the experimental TEIL course comprised the topics aimed at building theoretical knowledge of major concepts, distinctions, typologies and approaches involved in teaching English worldwide (English as an International Language, Teaching English as an International Language, English as a Lingua Franca, English as an International Lingua Franca, Lingua Franca Core, World/New Englishes, Circles of English), the practical skills of planning, delivering and evaluating instruction to multinational students (adapting materials, differentiating instruction, evaluating coursebooks, developing materials, assessing learners, investigating status of English) and attitudes (openness, tolerance, respect for diversity, adherence to standards). The full list of topics can be seen in Figure 5 below:

1. Sociocultural context of FLA

2. English as a global language

3. Changing English, World Englishes, regional varieties

4. Studying Englishes with corpora - corpus-based procedures in TEIL

5. Diverse contexts for ELT - ESL and World Englishes. Status of English in different countries

6. EIL language teacher: skills, competences, training, materials

7. ELF and culture. Teaching foreign languages in an intercultural world

8. Incorporating World Englishes and culture in curriculum design and lesson planning

9. Materials and aids in ELF. Culture and language in EFL coursebooks

10. Student presentations: reading/listening comprehension tasks based on non-British varieties/coursebook analysis of language and culture/

Figure 5. Syllabus for Teaching English as an International Language graduate course 


\subsection{Design and procedure}

The study comprised teaching a TEIL course with the use of selected interventions as described above: corpus-based linguistic investigations, student independent research into selected countries, lesson plan adaptation and evaluation and coursebook analysis. All these were interspersed with regular topics of the course as indicated above. At the beginning of the course the participants were administered a self-assessment survey to evaluate their perceived level of abilities within different components of global teaching competence (Appreciating values and cultures, Seeking standards and promoting diversity, Global teaching skills, Selecting resources and adapting materials). The participants were supposed to assess their skills on a scale from 1 to 5 , where 1 denoted "I feel completely unprepared to do that", while 5 meant "I feel very confident about it". Exactly the same survey was repeated at the end of the course to assess possible change in the perceptions of participants and assess the impact of the course. The data were processed with SPSS package version 24 .

\subsection{Results and findings}

As it is demonstrated in the tables below, the participants initially assessed different components of global teaching competence around the mid-point value (3) in the five-point scale (Mean BT before treatment). The mean values ranged between 3 and 4 , none of the components exceeded 4.0 (the highest scores were reported for statement 5 - "I can avoid bias or discrimination in my expression on the perceived roles of males and females in the culture of my students" and statement 7 "I can notice and appreciate my students' experiences in their own culture and in other cultures"). The reason for that might be the focus on intercultural teaching and Intercultural Communicative Competence in the teacher training programme at the B.A. level as well as general sensitivity to gender equality and family roles in the contemporary society. However, some areas of competence clearly fall behind - the ability to make use of historical/economical/technological factors influencing the relationship between L1 and L2 (statement $10-2.69$ ), doing linguistic research (statement 13 - 2.94), noticing the gap between mother culture and target culture and predicting its consequences on teaching (statement 28 - 2.88) and designing classroom materials based on New Englishes (statement $40-2.88$ ). This finding shows how an experimental programme within the Teaching English as an International Language course needs to expand the socio-cultural context of language teaching skills on the one hand and equip teacher trainees with the practical abilities of evaluating, planning and adapting instruction (either in terms of lesson plans, materials or activities) to fit the local cultures of learning on the other. These important findings were to be used in the design of quasi-experimental treatment. 
Table 1. Descriptive statistics (means, standard deviation before and after treatment and change)

\section{B1. Appreciating values and cultures}

\begin{tabular}{|c|c|c|c|c|c|}
\hline & $\begin{array}{l}\text { Mean } \\
\text { BT }\end{array}$ & SD & $\begin{array}{l}\text { Mean } \\
\text { AT }\end{array}$ & SD & Change \\
\hline $\begin{array}{l}\text { I can identify the expected variety of English } \\
\text { in the institution where I teach. }\end{array}$ & 3.37 & 1.63 & 4.13 & 1.09 & 0.75 \\
\hline $\begin{array}{l}\text { I can recognise the value and belief systems } \\
\text { that are a part of the culture of my students. }\end{array}$ & 3.25 & 1.34 & 4.31 & 0.79 & 1.06 \\
\hline $\begin{array}{l}\text { I can use techniques that do not reinforce } \\
\text { stereotypes of any culture, including the } \\
\text { culture of my students. }\end{array}$ & 3.56 & 1.41 & 4.50 & 0.73 & 0.94 \\
\hline $\begin{array}{l}\text { I can suit the expected level of participation } \\
\text { of my students in a task to the characteristics } \\
\text { of their culture. }\end{array}$ & 3.19 & 1.22 & 3.94 & 1.06 & 0.75 \\
\hline $\begin{array}{l}\text { I can avoid bias or discrimination in my } \\
\text { expression on the perceived roles of males } \\
\text { and females in the culture of my students. }\end{array}$ & 4.0 & 1.32 & 4.50 & 0.73 & 0.50 \\
\hline $\begin{array}{l}\text { I can use techniques which connect specific } \\
\text { language features (e.g., grammatical } \\
\text { categories, lexis, discourse) to cultural ways } \\
\text { of feeling, thinking and acting. }\end{array}$ & 3.31 & 1.25 & 4.19 & 0.75 & 0.88 \\
\hline $\begin{array}{l}\text { I can notice and appreciate my students' } \\
\text { experiences in their own culture and in other } \\
\text { cultures. }\end{array}$ & 4.0 & 1.32 & 4.69 & 0.48 & 0.69 \\
\hline $\begin{array}{l}\text { I can draw on my students' cultural } \\
\text { experiences by giving them an opportunity } \\
\text { to express these in oral or written tasks. }\end{array}$ & 3.56 & 1.41 & 4.38 & 0.72 & 0.81 \\
\hline $\begin{array}{l}\text { I can withdraw from imposing a values } \\
\text { system of either English or my own on my } \\
\text { students. }\end{array}$ & 3.25 & 1.06 & 3.88 & 0.72 & 0.63 \\
\hline
\end{tabular}




\section{B1. Appreciating values and cultures}

\begin{tabular}{llllll}
\hline & $\begin{array}{l}\text { Mean } \\
\text { BT }\end{array}$ & SD & $\begin{array}{l}\text { Mean } \\
\text { AT }\end{array}$ & SD & Change \\
\hline $\begin{array}{l}\text { I can identify and make good use of } \\
\text { historical/economical/technological factors } \\
\text { influencing the relationship between English } \\
\text { and the language of my students. }\end{array}$ & 2.69 & 1.08 & 3.81 & 0.91 & 1.12 \\
\hline $\begin{array}{l}\text { I can promote students' understanding } \\
\text { of how pragmatic norms can differ cross- } \\
\text { culturally. }\end{array}$ & 3.0 & 1.26 & 3.94 & 1.0 & 0.94 \\
\hline $\begin{array}{l}\text { I can identify my students' motivations, } \\
\text { beliefs and practice opportunities outside } \\
\text { class. }\end{array}$ & 3.5 & 1.26 & 4.38 & 0.72 & 0.88 \\
\hline $\begin{array}{l}\text { I can do research prior to class to investigate } \\
\text { target students' learning characteristics. }\end{array}$ & 2.94 & 1.29 & 4.0 & & \\
\hline
\end{tabular}

\section{B2. Seeking standards and promoting diversity}

\begin{tabular}{|c|c|c|c|c|c|}
\hline & $\begin{array}{l}\text { Mean } \\
\text { BT }\end{array}$ & SD & $\begin{array}{l}\text { Mean } \\
\text { AT }\end{array}$ & SD & Change \\
\hline $\begin{array}{l}\text { I can use my own English in writing and } \\
\text { speaking consistently according to one } \\
\text { adopted standard (e.g., RP, American } \\
\text { English). }\end{array}$ & 3.88 & 1.09 & 4.25 & 0.77 & 0.38 \\
\hline $\begin{array}{l}\text { I can evaluate my students' oral and written } \\
\text { performance according to the standard } \\
\text { expected in my institution. }\end{array}$ & 3.56 & 1.21 & 4.06 & 0.77 & 0.5 \\
\hline $\begin{array}{l}\text { I can appreciate my students' attempts to find } \\
\text { diverse listening and reading opportunities } \\
\text { in English. }\end{array}$ & 3.56 & 1.21 & 4.31 & 0.87 & 0.75 \\
\hline $\begin{array}{l}\text { I can explain to my students major } \\
\text { differences between key varieties of English } \\
\text { (e.g., between British English and American } \\
\text { English). }\end{array}$ & 3.44 & 1.36 & 4.19 & 0.83 & 0.75 \\
\hline
\end{tabular}


B2. Seeking standards and promoting diversity

\begin{tabular}{llllll} 
& $\begin{array}{l}\text { Mean } \\
\text { BT }\end{array}$ & SD & $\begin{array}{l}\text { Mean } \\
\text { AT }\end{array}$ & SD & Change \\
\hline $\begin{array}{l}\text { I can recognise the value of linguistic } \\
\text { diversity of language input in receptive skills } \\
\text { instruction. }\end{array}$ & 3.25 & 1.29 & 4.0 & 0.89 & 0.75 \\
\hline $\begin{array}{l}\text { I can reconcile the need for diversity with } \\
\text { the need for establishing a standard for my } \\
\text { students. }\end{array}$ & 3.0 & 1.37 & 3.81 & 0.91 & 0.81 \\
\hline $\begin{array}{l}\text { I can tell the difference between standard } \\
\text { and non-standard examples of usage. }\end{array}$ & 3.13 & 1.5 & 4.06 & 1.18 & 0.93 \\
\hline $\begin{array}{l}\text { I can select appropriate examples of usage for } \\
\text { grammar/vocabulary presentation. }\end{array}$ & 3.63 & 1.20 & 4.38 & 0.62 & 0.75 \\
\hline $\begin{array}{l}\text { I can give recognition to other languages } \\
\text { spoken by English speakers. }\end{array}$ & 3.44 & 0.96 & 4.31 & 0.60 & 0.87 \\
\hline $\begin{array}{l}\text { I can exemplify and appreciate English- } \\
\text { language interactions of non-native speakers. }\end{array}$ & 3.5 & 1.15 & 4.38 & 0.72 & 0.87 \\
\hline
\end{tabular}

B3. Global teaching skills

\begin{tabular}{llllll} 
& $\begin{array}{l}\text { Mean } \\
\text { BT }\end{array}$ & SD & $\begin{array}{l}\text { Mean } \\
\text { AT }\end{array}$ & SD & Change \\
\hline $\begin{array}{l}\text { I can set objectives that are equally } \\
\text { achievable for students in a multi-cultural } \\
\text { class. }\end{array}$ & 3.25 & 1.34 & 4.13 & 0.72 & 0.88 \\
\hline $\begin{array}{l}\text { I can diagnose and analyse the needs of } \\
\text { students in a multi-cultural class. }\end{array}$ & 3.13 & 1.45 & 4.13 & 0.72 & 1.0 \\
\hline $\begin{array}{l}\text { I can present lexical or grammatical items } \\
\text { in such a way so as to reach students coming } \\
\text { from different cultures. }\end{array}$ & 3.13 & 1.36 & 4.0 & 1.03 & 0.88 \\
\hline $\begin{array}{l}\text { I can use organisational forms of work } \\
\text { in relevance to the learning habits and } \\
\text { preferences of students coming from } \\
\text { different cultures. }\end{array}$ & 3.19 & 1.17 & 3.94 & 0.68 & 0.75 \\
\end{tabular}




\section{B3. Global teaching skills}

\begin{tabular}{|c|c|c|c|c|c|}
\hline & $\begin{array}{l}\text { Mean } \\
\text { BT }\end{array}$ & SD & $\begin{array}{l}\text { Mean } \\
\text { AT }\end{array}$ & SD & Change \\
\hline $\begin{array}{l}\text { I can see the gap between my own culture } \\
\text { and the culture(s) of my students and predict } \\
\text { its potential positive/negative consequences } \\
\text { on my teaching. }\end{array}$ & 2.88 & 1.09 & 4.0 & 0.63 & 1.12 \\
\hline $\begin{array}{l}\text { I can group international students in a way } \\
\text { that assures effective learning. }\end{array}$ & 3.06 & 1.12 & 4.0 & 0.82 & 0.94 \\
\hline $\begin{array}{l}\text { I can level out possible disparities between } \\
\text { different cultures of my students. }\end{array}$ & 3.06 & 1.24 & 4.06 & 0.68 & 1.0 \\
\hline $\begin{array}{l}\text { I can adapt my language instruction to } \\
\text { respect the local culture of learning. }\end{array}$ & 3.19 & 0.98 & 4.13 & 0.72 & 0.94 \\
\hline $\begin{array}{l}\text { I can identify my strengths and weaknesses } \\
\text { as a native/non-native teacher of English. }\end{array}$ & 3.88 & 0.81 & 4.38 & 0.62 & 0.5 \\
\hline $\begin{array}{l}\text { I can establish effective communication } \\
\text { code with my students, also at lower levels } \\
\text { (simplified L2, students' L1). }\end{array}$ & 3.56 & 1.26 & 4.25 & 0.68 & 0.69 \\
\hline
\end{tabular}

B4. Selecting resources and adapting materials

\begin{tabular}{llllll}
\hline & $\begin{array}{l}\text { Mean } \\
\text { BT }\end{array}$ & SD & $\begin{array}{l}\text { Mean } \\
\text { AT }\end{array}$ & SD & Change \\
\hline $\begin{array}{l}\text { I can make use of specimens of both high } \\
\text { and low English culture in a way relevant to } \\
\text { students coming from different cultures. }\end{array}$ & 3.19 & 1.05 & 4.19 & 0.91 & 1.0 \\
\hline $\begin{array}{l}\text { I can introduce interesting people from } \\
\text { different ethnic groups and their views and } \\
\text { opinions (e.g. novels, articles, news reports) } \\
\text { as well as from British or American points of } \\
\text { view. }\end{array}$ & 3.13 & 1.31 & 3.81 & 0.98 & 0.68 \\
\hline $\begin{array}{l}\text { I can offer opportunities for language/ } \\
\text { cultural/critical awareness that help learners } \\
\text { to reflect on their own use of language as } \\
\text { well as those of others. }\end{array}$ & & & & & \\
\hline
\end{tabular}


B4. Selecting resources and adapting materials

\begin{tabular}{|c|c|c|c|c|c|}
\hline & $\begin{array}{l}\text { Mean } \\
\text { BT }\end{array}$ & SD & $\begin{array}{l}\text { Mean } \\
\text { AT }\end{array}$ & SD & Change \\
\hline $\begin{array}{l}\text { I can provide materials that expose my } \\
\text { students to different varieties of language } \\
\text { (e.g. social, ethnic, gender, age). }\end{array}$ & 3.13 & 1.20 & 3.69 & 0.79 & 0.56 \\
\hline $\begin{array}{l}\text { I can provide materials that offer } \\
\text { opportunities to observe effective ways } \\
\text { of communication with people of various } \\
\text { backgrounds and value systems. }\end{array}$ & 3.06 & 1.29 & 4.06 & 0.77 & 1.0 \\
\hline $\begin{array}{l}\text { I can evaluate and select New Englishes texts } \\
\text { and recordings in accordance to my students' } \\
\text { needs. }\end{array}$ & 3.06 & 1.24 & 4.0 & 0.73 & 0.94 \\
\hline $\begin{array}{l}\text { I can design reading comprehension and } \\
\text { listening comprehension tasks in such a way } \\
\text { so as to make tasks based on New Englishes } \\
\text { texts achievable for my students. }\end{array}$ & 2.88 & 1.36 & 3.94 & 0.93 & 1.06 \\
\hline
\end{tabular}

On the other hand, as could be expected, the self-assessment of components of intercultural teaching competence exhibited by teacher trainees after treatment (Mean AT) generally rose, by a differing figure, ranging from around 0.5 to 1.12. This shows steady increase of awareness of different aspects involved in planning, implementing and evaluating situated language teaching, most notably, appreciation of values and cultures, awareness of standards and diversity, global teaching skills and materials evaluation and adaptation. This is a promising figure for future studies of experimental nature, which could use appropriate triangulation of data with teacher trainees' selfassessment cross-checked with observation for assessment of how they actually teach.

There is one figure that requires greater mention at this point - an exceptionally low increase of 0.38 was recorded for statement 14 - 'I can use my own English in writing and speaking consistently according to one adopted standard (e.g., RP, American English)'. It is evident that greater focus on the linguistic character of English, not only New Englishes, but also "old" varieties such as American English or Australian English is needed in much more systematic way. The linguistic component of the M.A. in English language teaching could be the appropriate place to establish such a systematic basis on which language teaching skills could be built.

Apart from descriptive statistics and means data indicated above, it is essential to apply appropriate statistical calculations to see whether there is a positive relationship between the participation in the quasi-experimental programme and self-assessment of specific components of global teaching competence, and whether the increase is of statistical significance, i.e., whether it is not 
attributable to chance. For this to happen, self-assessment data of participants were entered into SPSS version 24 program and subjected to the Wilcoxon Signed Rank test. The test (also known as the Wilcoxon matched pairs signed ranks test) is designed for use with repeated measures; that is, when the same participants are measured on two occasions, or under two different conditions. Here, the same group of teacher trainees had their self-assessment of global teaching competence probed into before and after the quasi-experimental treatment.

As a result, it turns out that for as many as 15 (out of 40) can-do statements from the instrument the statistical significance was equal or lower than 0.005 , as indicated in the table below, which shows that the increase in the self-rating of these competences was not subject to pure chance, but was systematically motivated. While, obviously, there are certain intervening variables that could contribute to the increase in teacher trainees' target language awareness, the participation in experimental treatment might have significantly contributed to that.

Moreover, it needs to be mentioned that had the significance level been set at a less stringent figure of 0.10 , it is only statement 14 that would not prove to be statistically significant. This finding might also corroborate the assumption that there is a relationship between participation in research-based and skill-oriented TEIL instruction as described above and the increased self-assessment of global teaching skills and target language awareness. However, the effect size (Cohen's $r$, Cohen 1988) for all of the cases above proved to be small $(r \leq 0.1)$, which suggests great caution needs to be taken before regarding the increase in self-assessment as high (which might be suggested only by descriptive statistics as demonstrated in Table 1).

\subsection{Pedagogical implications and limitations of the present study}

The present study is quasi-experimental in nature, however, due to its certain limitations the results are to be treated with a great amount of caution as highly preliminary. Most importantly, the treatment could not be randomized, with a control group as a point of reference for an experimental group due to the fact that the teaching specialization encompasses only one group in this particular university. Moreover, data triangulation was not accomplished due to logistical reasons - while it would be interesting to actually observe participants using the skills acquired during the experimental treatment in instruction, undertaking classroom observation was abandoned as unfeasible since they were in the extramural programme and came from very geographically dispersed locations. Moreover, not all participants were actually practicing teachers, which would make the situation of different student teachers difficult to compare. Finally, the researcher bias could not be avoided at that point - due to shortage of teacher training courses at this particular institution, the present researcher is commissioned to teach not fewer than two different courses with the experimental group each semester over the period of two years. This, naturally, largely influences student involvement and their self-assessment.

Even though the present study had only diagnostic value, intended to check the feasibility of the experimental treatment, find organizational pitfalls and test-drive the combinatory approach adopted in the course, it does yield some interesting points for further implementation and study. 


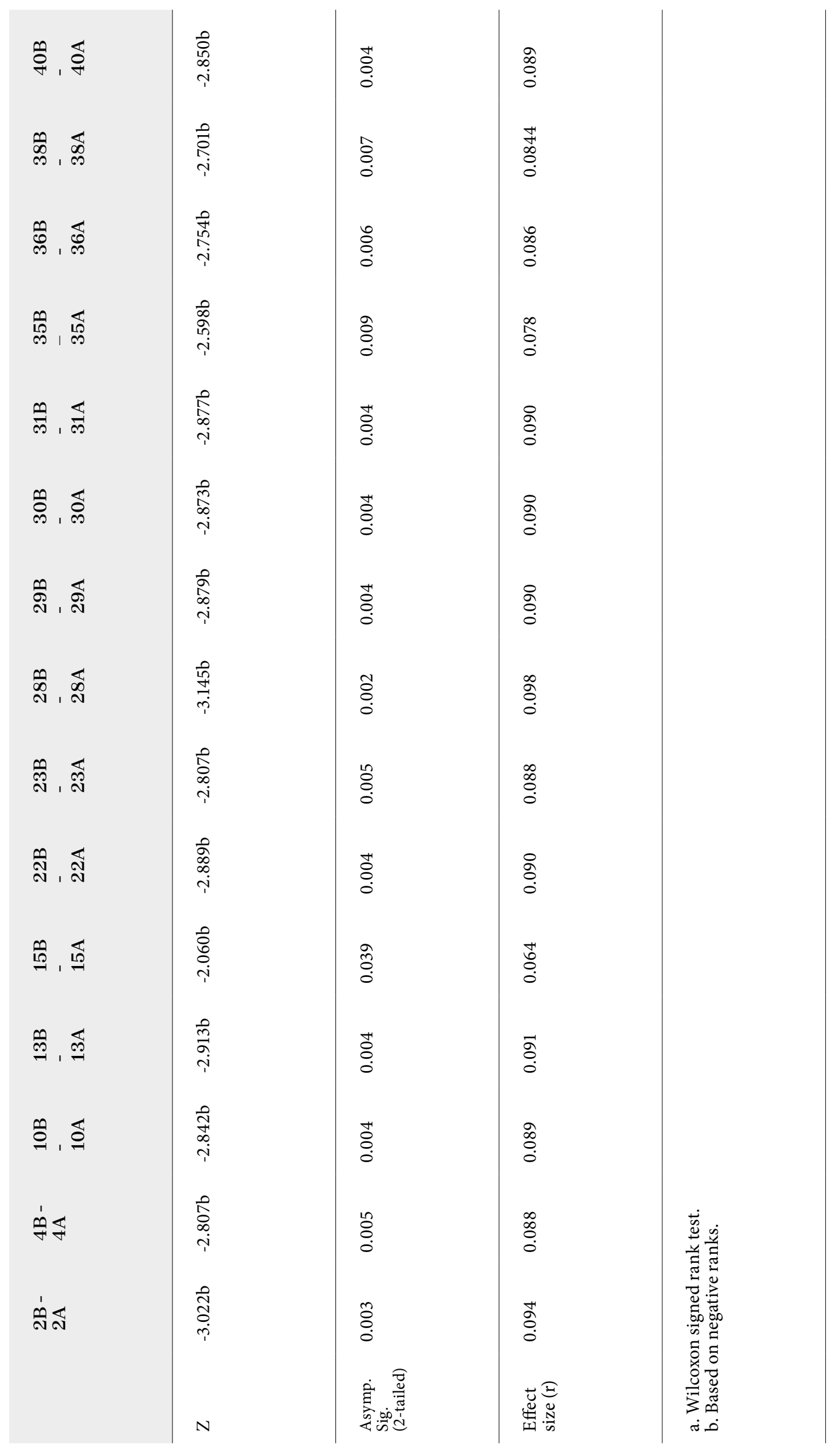

Table 2. Wilcoxon Signed Rank Test results for the research sample 
Most importantly, it can be concluded that linguistics and digital skills training can expand the teacher's skillset for more effective instruction, while changes in the status, role, perception, shape of the English language call for ample focus on NEs/WEs in the language classroom. A wider view on teacher language awareness needs to be adopted in the era of increased mobility, migrations or job openings abroad. In the present case, TLA is built by a combination of language data analysis, coursebook analysis, sociopolitical context and classroom materials development. Thus, the integration of theoretical linguistics, sociolinguistics and foreign language methodology can be achieved to increase English language teacher's mindset.

\section{Conclusion}

The quasi-experimental treatment revealed some important dilemmas of Teaching English as an International Language instruction that would need to be resolved and subjected to empirical investigation in future studies. First of all, should such courses head for Teaching English as an International Language, with the linguistic focus on Englishes, or, on Teaching English in International Contexts, namely on the way methodology is adapted to fit local contexts? As a result, to what extent should instruction be focused on knowledge and attitudes and to what on pedagogical skills, with either linguistic aspects of EIL/ELF/WE or pedagogical abilities of materials evaluation/adaptation becoming the centre of training? For most effective build-up of global teaching skills, TEIL focus would need to reappear in other components of the teacher training module. Since the participants were taught also other teacher training courses by the same researcher, spreading TEIL instruction across the whole module was possible (Lesson Observation, ELT Materials Evaluation, Language Testing). However, in other institutions this might not be the case, hence, instruction would need to be relegated to a dedicated TEIL class. Moreover, the question arises how explicit instructors should be about expanding global teaching skills, whether such an explicitly stated purpose would actually reflect needs of participants, and how to encompass this in assessment. These dilemmas would surely continue while similar studies are executed in the future.

Despite encountering a certain number of limitations, it might be concluded that we have at least managed to sketch the pathway to improved teacher training, encompassing awareness of New/World Englishes, research-based approach, corpus investigations and sociocultural context assessment in a single Teaching English as an International Language course. It is hoped that future studies would give clear answers to the questions and dilemmas posed above, and language teacher training will successfully benefit from other related disciplines such as sociolinguistics, corpus linguistics, language policy and planning for more comprehensive instruction increasing employability of university graduates.

\section{References}

Aston, G. 1997. Small and large corpora in language learning. In: J. Melia \& B. LewandowskaTomaszczyk (eds.), PALC '97 Proceedings. The First International Conference: Practical 
Applications in Language Corpora, 51-62. Łódź: Łódź University Press. http://www.sslmit.unibo.it/*guy/wudj1.htm (1 September 2018).

Baskaran, L. 1994. The Malaysian English mosaic. English Today 37: 27-32.

Baumgardner, R. J. 1990. The indigenization of English in Pakistan. English Today 21: 59-65.

Bernardini, S. 2000. Systematising serendipity: Proposals for concordancing large corpora with language learners. In: L. Burnard \& T. McEnery (eds.), Rethinking Language Pedagogy from a Corpus Perspective, 225-234. Frankfurt: Peter Lang.

Brown, H. D. 1994. Sociocultural factors. In: H. D. Brown (ed.), Principles of Language Learning and Teaching, 176-206. Englewood Cliffs: Prentice Hall.

Carter, R. 1995. How aware should language aware teachers and learners be? In: D. Nunan, R. Berry \& V. Berry (eds.), Language Awareness in Language Education, 1-15. Hongkong: University of Hong Kong.

Chambers, A. \& O'Sullivan, Í. 2004. Corpus consultation and advanced learners' writing skills in French. ReCALL 16(1): 158-172.

Cobb, T., Greaves, C. \& Horst, M. 2001. Can the rate of lexical acquisition from reading be increased? An experiment in reading French with a suite of on-line resources. Regards sur la didactique des langues secondes (P. Raymond \& C. Cornaire, Trans.), 133-153. Montréal: Éditions logique.

Cobb, T. 1997. Is there any measurable learning from hands-on concordancing? System 25: 301-315.

Cobb, T. 1998. Breadth and depth of lexical acquisition with hands-on concordancing. Computer Assisted Language Learning 12(4): 345-360.

Cohen, J. 1988. Statistical Power Analysis for the Behavioral Sciences (2nd ed.). Hillsdale, NJ: Lawrence Erlbaum Associates.

Crystal, D. 1999. The future of Englishes. English Today 15: 10-20.

Crystal, D. 2005. English as a Global Language. Cambridge: Cambridge University Press. (Original work published 1997).

Crystal, D. 2010. The future of Englishes: going local. In: R. Facchinetti, D. Crystal \& B. Seidlhofer (eds.), From International to Local English - And Back Again, 17-25. Bern: Peter Lang.

de Schryver, G. M. 2002. Web for/as corpus: A perspective for the African languages. Nordic Journal of African Studies 11(2): 266-282.

Dziubalska-Kołaczyk, K. 2005. Native or non-native? This is the question: Which English to teach in the globalizing world? In: Proceedings of PTLC 2005. London: Department of Phonetics and Linguistics, UCL, CD-ROM. https://www.ucl.ac.uk/pals/study/cpd/cpd-courses/ptlc/ proceedings_2005/ptlcp67. (30 August 2016).

Farrell, T. S. C., \& Martin, S. 2009. To teach Standard English or World Englishes? A balanced approach to instruction. English Teaching Forum 2: 2-7.

Gaskell, D. \& Cobb, T. 2004. Can learners use concordance feedback for writing errors? System 32(3): 301-319. 
Hadley, G. 2002. Sensing the winds of change: An introduction to Data-Driven Learning. RELC Journal 33(2): 99-124.

Hall, G. 2011. Exploring English Language Teaching. Language in Action. London: Routledge.

Harmer, J. 2007. The Practice of English Language Teaching. Harlow: Longman. (Original work published 1983).

Hazen, K. 2001. Teaching about dialects. ERIC Digest. http://files.eric.ed.gov/fulltext/ ED456674.pdf. (30 August 2016).

Horst, M., Cobb, T. \& Nicolae, I. 2005. Expanding academic vocabulary with a collaborative online database. Language Learning \& Technology 9(2): 90-110.

Johns, T. 1991. Should you be persuaded: two samples of data-driven learning materials. English Language Research Journal 4: 1-16.

Kachru, B. 1994. English in South Asia. In: R. Burchfield (ed.), Cambridge History of the English Language, Vol. V. English in Britain and Overseas, 497-553. Cambridge: Cambridge University Press.

Kaszubski, P. 2006. Web-based concordancing and ESAP writing. Poznań Studies in Contemporary Linguistics 41: 161-193.

Kennedy, C. \& Miceli, T. 2001. An evaluation of intermediate students' approaches to corpus investigation. Language Learning \& Technology 5 (3): 77-90.

Krajka, J. 2015. Towards target language awareness of English language teachers - three stories of teacher education projects. Journal of Education 4(1): 45-51. http://journal.ibsu.edu.ge/index.php/sje/article/view/662/555. (1 September 2018).

Lee, D. \& Swales, J. 2006. A corpus-based EAP course for NNS doctoral students: Moving from available specialized corpora to self-compiled corpora. English for Specific Purposes 25: 56-75.

Leńko-Szymańska, A. 2005. Korpusy w nauczaniu języków obcych. In: B. LewandowskaTomaszczyk (ed.), Podstawy jezzykoznawstwa korpusowego, 221-239. Łódź: Wydawnictwo Uniwersytetu Łódzkiego.

Lewandowska-Tomaszczyk, B. 2001. Acquisition of lexis, language corpora and foreign language teaching. In: B. Lewandowska-Tomaszczyk \& I. Czwenar (eds), A New Curriculum for English Studies. Piotrków: College Press.

Maley, A. 2010. The reality of EIL and the myth of EFL. In: C. Gagliardi \& A. Maley (eds.), EIL. EFL, Global English: Teaching and Learning Issues vol. 96, 25-44. Bern: Peter Lang AG, International Academic Publishers.

Marinov, S. 2013. Training ESP students in corpus use - challenges of using corpus-based exercises with students of non-philological studies. Teaching English with Technology 13(4): 49-76.

Matsuda, A. 2002. 'International understanding' through teaching world Englishes. World Englishes 21(3): 436-440.

Matsuda, A. 2003. The ownership of English in Japanese secondary schools. World Englishes 22(4): 483-496.

Mesthrie, R. 1992. Lexicon of South African English. Leeds: Peepal Tree Press. 
Mesthrie, R. 1993a. English in South Africa. English Today 33: 27-33.

Mesthrie, R. 1993b. South African Indian English. English Today 34: 12-16.

Rinvolucri, M. 2006. What sort of standard does English as a Lingua Franca (ELF) need to reach? The Teacher 12(44): 35-36.

Schumann, J. 1976. Social distance as a factor in Second Language Acquisition. Language Learning 26(1): 135-143.

St. John, E. 2001. A case for using a parallel corpus and concordancer for beginners of a foreign language. Language Learning \& Technology 5(3): 185-203.

Yoon, H. \& Hirvela, A. 2004. ESL student attitudes towards corpus use in L2 writing. Journal of Second Language Writing 13: 257-283.

\section{***}

Jarosław Krajka, Director of Institute of German Studies and Applied Linguistics at Maria CurieSkłodowska University in Lublin, Poland. He has a Ph.D. degree in Computer-Assisted Language Learning and a habilitated doctor degree in EFL teacher training. He authored two books on CALL (English Language Teaching in the Internet-Assisted Environment and The Language Teacher in the Digital Age) and co-authored two more on EFL methodology (with Hanna Komorowska, Monolingualism - Bilingualism - Multilingualism. The Teacher's Perspective) and intercultural communication (with Weronika Wilczyńska and Maciej Mackiewicz, Komunikacja interkulturowa, Wprowadzenie). He is the editor-in-chief of a Scopus-listed journal Teaching English with Technology (http://tewtjournal.org). 